UDK 339.5/.9(4-672EU:510)

Biblid 0543-3657, 72 (2021)

God. LXXII, br. 1181, str. 71-86

Pregledni rad

Primljen: 10.10.2020.

Prihvaćen 5.2.2021.

doi: https://doi.org/10.18485/iipe_mp.2021.72.1181.4

Zoran DABETIĆ1

Mira ŠOROVIĆ ${ }^{2}$

\title{
EU i NR Kina - politički \\ i ekonomski aspekt saradnje
}

\section{SAŽETAK}

Ovaj rad nastoji da analizira politički i ekonomski aspekt saradnje Evropske unije i Kine, kroz prizmu zajedničkih ekonomskih interesa i privredne komplementarnosti. Autori u uvodnom dijelu govore o istorijskom razvitku Kine kao države, te njenoj transformaciji kako u političkom tako i u ekonomskom smislu. Posebna pažnja posvećena je istorijskom razvoju odnosa između Kine i Evropske unije, sa akcentom na razvijanje ekonomske, političke i trgovinske saradnje, čiji se odnosi, između ostalih, ističu kao ključni u spoljnopolitičkim prioritetima Kine. Pored toga, u kratkim crtama biće pojašnjena Inicijativa „Pojas i put”, ali biće riječi i o pandemiji virusa COVID-19, kao i o presudnoj ulozi Kine u ovoj pandemiji koja je zadesila i promijenila svijet.

Ključne riječi: EU, Kina, politika, istorija, geoekonomija, svjetski poredak, Inicijativa „Pojas i put", COVID-19.

${ }^{1}$ Doktorand na Humanističkim studijama, Univerzitet Donja Gorica, Podgorica, Crna Gora.

E-mail: zoran.dabetic@udg.edu.me

${ }^{2}$ Doktorantkinja na Humanističkim studijama, Univerzitet Donja Gorica, Podgorica, Crna Gora.

E-mail: mira.sorovic@udg.edu.me 


\section{Uvodne napomene}

„Kina je civilizacija koja se pretvara da je nacija." ${ }^{3}$

Politikolog Lisjen Paj

Iako je ujedinjena kao jedinstvena država još 221. godine p.n.e. od strane cara Kin Ši Huanga, Kina je sve do XIX vijeka zagovarala jedinstvenu perspektivu odnosa prema spoljnom svijetu, čija suština i smisao se ogledala u kineskom terminu zhohgguo, koji označava "srednju državu". ${ }^{4}$ Shodno tome, ključni aspekti ovog pojma ističu da Kina posjeduje kulturni identitet, koji nije zasnovan na pukoj teritoriji i nacionalnosti, već na vjerovanju u kinesku superiornost. Upravo zbog toga, konfučijanizam je zauzeo centralno mjesto u ovom jedinstvenom sistemu vjerovanja, naročito zbog akcentovanja paternalističke hijerarhije, odnosno postizanja sveukupne društvene harmonije. ${ }^{5}$ Podsjećanja radi, osvajači iz Mongolije i Mandžurije, tokom XIII odnosno XVII vijeka, uspjeli su da sa vlasti svrgnu postojeće dinastije, međutim nisu uspjeli da unište temeljne vrijednosti i suštinu na kojima ovo društvo već vjekovima počiva. ${ }^{6}$

Dugoročni globalni cilj Kine je multipolarni svjetski poredak, kojem velike svjetske sile ne sarađuju na račun trećeg, ne sukobljavaju se, a međunarodne organizacije sposobne su da obuzdaju unipolarno ponašanje. Dakle, akademski krugovi u Kini su razvili vanjskopolitički koncept posebnosti pod kojim Kina ne uslovljava model ekonomije, ni društva koji bi trebale slijediti druge države, te da nije sila superiorna drugima - nasuprot konceptu izuzetnosti prema kojem je Amerika superiorna ostalim državama, te model koji treba slijediti svijet. ${ }^{7}$ Stoga, strateški interes Kine nije hegemonija, nego sistemsko nastojanje da se odnos snaga u regionu ne razvije u pravcu neke antikineske koalicije, koja bi imala za cilj da promijeni vođstvo Komunističke partije Kine i socijalizam sa kineskim karakteristikama, ugrožavajući na taj način njen teritorijalni suverenitet $\mathrm{i}$ integritet, ali i održiv ekonomski razvoj.

Teorije „opasne Kine” preovladavaju od početka 2000. godine i one rast ekonomske snage Kine objašnjavaju negativno kao opasnost za stabilnost

${ }^{3}$ Tim Maršal, "Zatočenici geografije“, Laguna, Beograd, 2019, str. 35.

${ }^{4}$ John Baylis, Steve Smith and Patricia Owens, "The Globalization of World Politics", Oxford University Press, Oxford, 2014, p. 86.

${ }^{5}$ Ibidem

${ }^{6}$ Ibidem

${ }^{7}$ Jasna Plevnik, Stjepan Mesić i Ljubo Jurčić, „Kina na Balkanu”, Plejada, Zagreb, 2012, str. 14-55.

$72{ }^{8}$ Ibidem, str. 66-123. 
svjetskog poretka, odnosno Zapada. ${ }^{9}$ Uglavnom polaze od toga da će, ukoliko dođe do transfera ekonomske snage Kine u područje vojne i političke moći, prevladati trendovi promjene svjetskog poretka u pravcu kineskog unipolarizma, a takav obrt ne bi mogao proći bez vojnog sukoba Kine i Amerike. Stoga, vizija Kine nekog budućeg svjetskog poretka je multipolarizam globalnih regija, zato što ovakav poredak osigurava više stabilnosti od aktuelnog. ${ }^{10}$

„Vjerujem da možemo i da bismo trebali zauzeti svoje mjesto na svjetskoj pozornici; ne zbog taštine, nego zato što imamo što ponuditi. (...) Želim Europu koja predvodi. Kada Europska unija nastupa jedinstveno, možemo promijeniti svijet."11

Žan Klod Junker

Kada je riječ o Evropi i o razvoju međunarodnih odnosa na ovom kontinentu, $\mathrm{u}$ postratnom periodu (neposredno nakon Drugog svjetskog rata) javlja se ideja o ujedinjavanju zemalja u cilju postizanja zajedničkog mira i stabilnosti, te razvijanju funkcionalne demokratije i zajedništva, odnosno stvaranju ujedinjene Evrope. Po mišljenju velikog broja autora, ideja o ujedinjenoj Evropi se javlja mnogo ranije, u vrijeme stvaranja Platona i Aristotela, preko mišljenja Imanuela Kanta i Monteskjea, te čuvenih djela i rečenica Viktora Igoa. Međutim, ovakav oblik ujedinjenja u pravnom i formalnom smislu, ipak je sačekao sredinu XX vijeka. ${ }^{12}$

„Proces stvaranja i razvoja EU, pridruživanja i pristupanja novih država Uniji, naziva se jednim imenom proces evropskih integracija." ${ }^{13}$ Evropska unija danas broji 27 članica. Posljednje proširenje je bilo 2013. godine, kada je članica EU postala Hrvatska, dok je tokom ove kalendarske godine, Velika Britanija ${ }^{14}$ okončala proces pregovora za napuštanje Evropske unije.

\footnotetext{
${ }^{9}$ Ibidem

${ }^{10}$ Ibidem

${ }^{11}$ Zvanični sajt Evropske komisije, dostupno na: https://ec.europa.eu/commission/ priorities/state-union-speeches_hr, pristup: 24.12.2020.

${ }^{12}$ Zoran Dabetić, „Uporedna analiza iskustava Crne Gore i Slovenije u procesu pristupanja Evropskoj uniji: analiza spoljne politike", Magistarski rad, Univerzitet Donja Gorica, Podgorica, 2019, str. 7.

${ }^{13}$ Gordana Đurović, „Evropska unija i Crna Gora: proces pristupanja”, Nacionalna biblioteka Crne Gore, Podgorica, 2017, str. 9.

${ }^{14}$ Velika Britanija je nakon 47 godina članstva, 31. januara 2020. godine zvanično napustila EU (formalno pokrenuvši Član 50 Ugovora o Evropskoj uniji). Na taj način, najveći svjetski trgovački blok, izgubio je 15\% svoje ekonomije, svog najvećeg vojnog potrošača, ali i jednog od vodećih svjetskih finansijskih centara - London. (za više
} 
„BDP EU čini oko 22\% BDP svijeta, dok se u EU zemlje posljednjih godina ulaže oko $30 \%$ ukupnih stranih direktnih investicija svijeta (od čega je 55\% intra-EU investiranje)." 15

Počeci Evrope kakvu danas poznajemo datiraju još iz 1948. godine, kada je stvorena Carinska unija Beneluksa (Holandija, Belgija i Luksemburg), a dvije godine kasnije, zvanično je osnovana Evropska zajednica za ugalj i čelik, čije je stvaranje inicirao tadašnji ministar spoljnih poslova Francuske Robert Šuman, a koja je imala za cilj "ukidanje tarifnih kvota unutar zajedničkog tržišta za ugalj, čelik, koks i gvožđe" ${ }^{16}$ Dalji razvitak teče do „1957. godine kada su osnovane Evropska ekonomska zajednica i Evropska zajednica za atomsku energiju (Rimski ugovori), a odnosili su se na nastanak carinske unije, postepeno ukidanje necarinskih barijera, te na zajedničku politiku", ${ }_{17}$ zatim stvaranja Jedinstvenog evropskog akta (1986), pa sve do Ugovora o EU u Mastrihtu (1992), kada je zvanično osnovana EU, kao i Evropska monetarna unija (EMU), Ugovora iz Amsterdama (1997), čije su karakteristike bile "renumeracija članova osnivačkih akata, unaprijeđenje oblasti pravosuđa i unutrašnjih poslova", ${ }^{18}$ Ugovora iz Nice (2001), gdje su na najbolji mogući način usvojena pravila glasanja, pa sve do 2007. godine, kada je potpisan Ugovor u Lisabonu, koji je na snagu stupio dvije godine kasnije, a kojim ,se definiše nov način organizacije i rada Evropske unije" ${ }^{19}$

Shodno svemu navedenom, neophodno je istaći da odnosi između dva strateški važna partnera sežu još od XX vijeka, dok je tokom vremena, upravo zahvaljujući trgovini i privredi, ovo prijateljstvo ojačano i unaprijeđeno zajedničkim djelovanjem na međunarodnoj sceni. Takođe, upravo zbog aktuelnosti same teme, ne smijemo zaboraviti da je mnogo naučnih radova i okruglih stolova vođeno na ovu temu, međutim, zbog dinamike i konstantnog unaprijeđenja ove saradnje postojala je potreba da se u kratkim crtama predoči istorijski prikaz ovih odnosa.

informacija pogledati: EUR-Lex: https:// eur-lex.europa.eu/content/news/Brexit-UKwithdrawal-from-the-eu.html i UK Parliament: https://www.parliament.uk/ business/publications/research/eu-referendum/leaving-the-european-union/, pristup: 25.12.2020).

${ }^{15}$ Gordana Đurović, op. cit., str. 10.

${ }^{16}$ Ilija J. Džombić, „Evropske inicijative i institucije” - II izdanje, Friedrich-Ebert-Stiftung, Sarajevo, 2012, str. 30.

${ }^{17}$ Gordana Đurović, op. cit., str. 16.

${ }^{18}$ Ibidem

$74 \quad{ }^{19}$ Ibidem 


\section{Istorijski prikaz razvoja odnosa Evropske unije $i$ Kine}

NR Kina, nakon lansiranja Maove neodgovarajuće politike kineskog razvoja „,veliki skok unaprijed” (1958) i „,kulturna revolucija” (1966), ${ }^{20}$ uvela je mnogobrojne reforme unutar kineskog društva, što se pozitivno odrazilo na njeno otvaranje ka svijetu. Ove promjene i dešavanja u najmnogoljudnijoj državi svijeta obilježile su kraj 70-ih godina XX vijeka. Neophodno je podvući da su Kina ${ }^{21}$ i tadašnja Evropska ekonomska zajednica (EEZ) započele diplomatske odnose tek 1975. godine. Međutim, usljed trajanja Hladnog rata, one nisu davale prioritet ekonomskim interesima u okviru njihovih razgovora, odnosno prilikom razvoja bilateralnih odnosa, iz čega proizilazi da je bilateralan odnos imao sekundarnu i podređenu prirodu. Prema tome, u tom periodu (1975. godine), trgovinska razmjena bilježila je vrijednosti od 2,4 milijarde američkih dolara. ${ }^{22}$

Kina je započela proces reformi i otvaranja svog tržišta ka svijetu 1978. godine. Iste godine, potpisan je prvi trgovinski sporazum između EEZ i Kine, tzv. "trgovinskih država", ${ }^{23}$ da bi kasnije isti bio zamijenjen sporazumom o trgovini i saradnji 1985. godine i kasnije proširen na oblasti ulaganja i razvojne pomoći. Godine 1979, EEZ i Kina su postigle sporazum o trgovini tekstilnim proizvodima. ${ }^{24}$ Dakle, tokom sedamdesetih i osamdesetih godina prošlog vijeka, kineska spoljna trgovina bila je podređena nacionalnom ekonomskom razvoju. Svrha izvoza bila je sticanje stranih valuta, kako bi se kupila neophodna tehnologija i oprema za dalji ekonomski razvoj države. Dodatno, nakon uvođenja ekonomskih sankcija Kini, države članice EEZ imale su različita mišljenja o tome kako i na koji način je potrebno dalje razvijati odnose sa Kinom, jer je interesovanje za kinesko tržište bilo u porastu. ${ }^{25}$ Stoga, godine 1992. došlo je do normalizacije trgovinskih odnosa između EEZ i Kine

${ }^{20}$ Henri Kisindžer, ,,Svetski poredak“, CID, Podgorica, 2015, str. 173.

${ }^{21} \mathrm{U}$ tom periodu, NR Kina je bila u fazi tranzicije, pa je zavisila od finansijskih ulaganja, visokorazvijene tehnologije, kao i iskustva bogatih zemalja Zapadne Evrope.

${ }^{22}$ Chen Xin, "Policy Evolution of the China-EU Trade and Economic Relantioship" Working Paper Series on European Studies, Institute of European Studies, Chinese Academy of Social Sciences, Beijing 100732, Vol. 3, No. 4, 2009, pp. 2-3.

${ }^{23}$ Shan Wen Hua, "Ou Meng Dui Hua Tou Zi de Fa Lv Kuang Jia: Jie Gou Yu Jian Gou" (The Law Framework of EU Investment in China), Bei Jing Da Xue Chu Ban She, 2007, p. 11, preuzeto iz: Chen Xin, "Policy Evolution of the China-EU Trade and Economic Relantioship" Working Paper Series on European Studies, Institute of European Studies, Chinese Academy of Social Sciences, Beijing 100732, Vol. 3, No. 4, 2009, p. 4.

${ }^{24}$ Ibidem

${ }^{25}$ Youri Devuyst, Jing Men, “The European Union Transformed: Community Method and Institutional Evolution from the Schuman Plan to the Constitution for Europe", Chinese Edition, Beijing: China Remin University Press, pp: 131, preuzeto iz: Chen Xin, op. cit., p. 5. 
(izuzetak je trgovina oružjem), dok je bilježenje ekonomskog rasta Kine karakterisalo naredne godine. Prekretnicu u odnosima predstavlja Zakon o spoljnoj trgovini koji je usvojio kineski Nacionalni narodni kongres 1994. godine, što je dalo podsticaj za liberalizaciju kineske međunarodne trgovine, te urušilo monopol nad kojim su prethodno dominirala državna trgovačka preduzeća. Privatne kompanije su počele da igraju sve značajniju ulogu, dok se trgovina između EU i Kine vratila na staru stazu. Kao kruna njihove međusobne saradnje navodi se akcentovanje Nove azijske strategije, odnosno Dugoročni dokument o politici evropsko-kineskih odnosa, pri čemu je otvoreno novo poglavlje $u$ istoriji odnosa Kine i Evropske unije. ${ }^{26}$

Kako je vrijeme odmicalo, trgovinska saradnja je nastavljena i povećana sa još većim kapacitetom početkom XXI vijeka. Međutim, iako je došlo do povećanja kvantitativne i kvalitativne saradnje, ostavile su prostor za međusobne razmirice:

1. Problem evropskog deficita (2007);

2. Problem nedovoljnosti zakonske regulative (kineska kontrola i efektivna zaštita intelektualnog vlasništva) i obezvređenje kineske valute, juana.

Neophodno je istaći da se odnosi između NR Kine i EU ne zasnivaju isključivo na privredi. Kao aktuelna navode se pitanja: ukidanje embarga na trgovinu oružja, nametnut od strane EU NR Kini, pitanje Tajvana, nemiješanja $u$ unutrašnja pitanja - ljudska prava, kao i sigurnosna pitanja, jer je potrebno istaći da obije strane nastoje biti globalni akteri.

\section{Saradnja kao spoljnopolitički prioritet}

Prema riječima Fenga Džongpinga (Feng Zhongping), kineska spoljna politika se reflektuje na tri ključne dimenzije, koje predstavljaju: odnose NR Kine sa susjednim zemljama; odnose NR Kine sa zemljama u razvoju, kao i odnose sa glavnim svjetskim silama: SAD, Rusijom, Evropom i Japanom. ${ }^{27}$

Prema zajedničkoj ocjeni kineskih i evropskih zvaničnika, kineskoevropski odnosi su na najvišem niovou u istoriji, a ,izgradnja sveobuhvatnih, snažnih i trajnih odnosa s Kinom jedan je od najvažnijih vanjskopolitičkih prioriteta EU za 21. stoljeće" ${ }^{28}$ Krajem XX vijeka, premda za dobre uzajamne odnose, navode se sljedeće pretpostavke:

${ }^{26}$ Chen Xin, op. cit., pp. 5-6.

${ }^{27}$ Feng Zhongping, "A Chinese perspective on China-European relations", European Union Institute for Security Studies (EUISS), 2008, p. 77.

${ }^{28}$ Ozren Baković, ,'Miroljubivi uspon - nova kineska vanjskopolitička teorija“, Politička misao, Vol. XLI, (2004), br. 1, str. 126-137. Citirano prema izjavi Romana Prodija (Romano Prodi) na predavanju u Kineskoj akademiji društvenih znanosti održanom 14. maja 2004. tokom službene posjete Kini. 
a) Između EU i Kine ne postoji sukob fundamentalnih interesa, ni u geopolitičkom smislu, niti u strateškim namjerama. Ne postoji uzajamna prijetnja ni u kom pogledu, a povratkom Hong Konga (1997) i Makaoa (1999) matici, uklonjena su i otvorena pitanja preostala iz istorije;

b) Kina i EU su dva važna svjetska tržišta i njihova gospodarstva su komplementarna, što otvara veliki potencijal za saradnju u različitim područjima (prvenstveno trgovinska razmjena); i

c ) Kina i Europa, kao dvije stare civilizacije, imaju visoko razvijenu kulturu, umjetnost, odgovarajuće prednosti na području nauke, tehnologije i obrazovanja, što ih prirodno predisponira na učenje jednih od drugih. ${ }^{29}$

Kinu posebno zanimaju iskustva EU u procesu regionalne integracije, te je na sastanku Romana Prodija sa kineskim premijerom Ven Điabaom (Wen Jiabao), 14. maja 2004. godine, dogovoreno da se institucionalizira politički dijalog o ovoj temi. Promovišući miroljubivi uspon u regiji, Kina ozbiljno razmatra mogućnost da se, po uzoru na EU, cijela istočna Azija postupno integrira u svojevrsnu „Istočnoazijsku zajednicu” (EA Community). Proces je već započeo u okvirima ASEAN-a. ${ }^{30}$ Kina ne samo da dijeli viziju, već je spremna i aktivno poduprijeti integrisanje sada odvojenih procesa (mehanizmi 10+1, 10+3, uspostavljanje slobodnih trgovinskih zona i dr.) ne bi li se u budućnosti realizovala ideja Istočnoazijske zajednice. ${ }^{31}$

Snažan ekonomski rast, zatim prateće povećano političko značenje, postavljaju za Kinu nove izazove i odgovornosti na svjetskoj sceni. To je u prvom redu nastavak procesa integracije $\mathrm{u}$ globalne privredne tokove $(\mathrm{u}$ novembru 2001. godine Kina je pristupila Svjetskoj trgovinskoj organizaciii), nakon čega je povećan angažman i aktivnija uloga u rješavanju međunarodnih problema, prvenstveno kroz povećanu aktivnost $\mathrm{u}$ Ujedinjenim nacijama. Takođe, neophodno je istaći da za razliku od prije deset godina, Kina danas u regionalnim i svjetskim pitanjima zauzima sve sofisticiraniji, samouvjereniji i konstruktivniji pristup. ${ }^{32}$

${ }^{29}$ Mei Zhaorong, "New Phase In China-EU Relations", Foreign Affairs Journal, 2004, 71, pp. 33-34.

${ }^{30}$ Ozren Baković, op. cit., str. 133. (Godine 2003. na devetom sastanku predsjednika država i vlada ASEAN-a donesena je tzv. „Druga balijska deklaracija”. Prva je donesena 1976. godine, kada je na Baliju održan prvi samit ASEAN-a kojom se predviđa postupno uspostavljanje Aseanske sigurnosne zajednice, Aseanske privredne zajednice i Aseanske društveno-kulturne zajednice).

${ }^{31}$ Ruan Zongze, predavanje na temu: "China's Peaceful Rise And Chinese Foreign Policy", 3. travnja 2004.

${ }^{32}$ Evan S. Medeiros and Taylor Fravel, "China's New Diplomacy", Foreign Affairs, 2003, p. 22. 


\section{Trgovinska i ekonomska saradnja}

Prema podacima Evropske komisije, Evropska unija i Kina su dva najveća svjetska trgovca. Trenutno, Kina je drugi najveći trgovinski partner EU (odmah nakon SAD) dok je EU najveći kineski trgovinski partner. ${ }^{33}$ Shodno navedenom, EU je posvećena otvaranju trgovinskih odnosa sa Kinom. Međutim, EU želi da bude sigurna da Kina posluje na primjerenom nivou: poštujući prava intelektualne svojine, te ispunjavajući sve nametnute obaveze kao članica Svjetske trgovinske organizacije. ${ }^{34}$

Podsjećanja radi, tokom 2013. godine, pokrenuti su pregovori o Ugovoru o ulaganju, sa težnjom da se investitorima iz obije države pruži predvidljiv, odnosno dugoročan pristup tržištima, na način što će biti zaštićeni investitori i njihova ulaganja. Takođe, EU je 2016. godine usvojila Novu strategiju o Kini kojom se definiše odnos Evropske unije sa Kinom u narednih pet godina. Strategija promoviše reciprocitet, ravnopravne uslove na tržištu, kao i fer konkurenciju u svim oblastima saradnje. Strategija takođe uključuje Trgovinsku agendu sa snažnim fokusom koji se odnosi na poboljšanje mogućnosti pristupa tržištu, uključujući i pregovore o Sveobuhvatnom sporazumu o ulaganju, te se bavi prekomjernim kapacitetom i poziva Kinu da sa velikim ambicijama djeluje na multilateralnom nivou. ${ }^{35}$

Narodna komisija za razvoj i reforme kao jedan od ključnih ciljeva dugoročne ekspanzije Kine definisala je prijekopotrebno geografsko prebacivanje proizvodnje sa nižom dodatnom vrijednošću, $u$ zemlje $u$ razvoju. Shodno tome, akcenat je stavljen na širenje infrastrukturne i distribucijske mreže koja će omogućiti olakšan pristup dragocjenim prirodnim resursima, ali i geografski interesantnim područjima, kao što je

${ }^{33}$ Preuzeto sa: European Commission, URL: https:/ / ec.europa.eu/trade/policy/countriesand-regions/countries/china/ Pristupljeno: 12.5.2020. Trgovinski promet na dnevnom nivou kreće se okvirno i do milijardu evra. Dakle, glavni uvozni kineski proizvodi u EU su: industrijska roba i roba široke potrošnje, mašine i oprema, obuća i odjeća, dok su glavni izvozni proizvodi EU ka Kini: mašine i oprema, motorna vozila, letjelice i hemikalije. Shodno tome, neophodno je istaći da trgovina usluga između EU i Kine iznosi više od 10\% ukupne trgovine robom, dok izvoz usluga EU čine više od 19\% ukupnog EU izvoza robe.

${ }^{34}$ NR Kina je postala članica ove organizacije 2001, kada je uvela značajne ekonomske reforme. Međutim, bez obzira na navedeno, Kina se i dalje suočava sa: manjkom transparentnosti; industrijske politike i necarinske mjere koje diskriminišu strane kompanije; snažna intervencija vlade u ekonomiji, (što je uzrokovalo dominanatan položaj državnih firmi, nejednak pristup subvencijama i jeftinom finansiranju), kao i loša zaštita i sprovođenje prava intelektualne svojine. Sve su ovo problemi koji usporavaju napredak Kine na globalnom nivou. Detaljnije vidjeti na: European Commission, URL: https://ec.europa.eu/trade/policy/countries-and-regions/ countries/china/, pristup: 12.5.2020.

${ }^{35}$ Ibidem 
slučaj sa Zapadnim Balkanom. Jer, trenutna ekonomska politika Kine, u ovom dijelu svijeta, usmjerena je prvenstveno na energetske i infrastrukturne projekte, sa naznakom proizvodnih aktivnosti, te olakšanom pristupu tržištu Evropske unije o čemu svedoče brojni investicioni projekti kineskih firmi (npr. izgradnja autoputa u Crnoj Gori, Bar-Boljare). ${ }^{36}$ Prema tome, Inicijativa ",Pojas i put" ${ }^{\prime 37}$ predstavlja infrastrukturnu i transportnu mrežu koja će ostvariti nove saradnje i produbiti odnose Kine sa svojim postojećim partnerima. Dakle, zemlje Centralne i Istočne Evrope ${ }^{38}$ postaju sve važnije u kineskoj spoljnoj politici, naročito nakon što su uvrštene u „Novi put svile". ${ }^{39}$ Ipak, kineska politika kojom se plasira višak kapitala, s ciljem produbljivanja pristupa na stranim tržištima, putem naprednih tehnologija i prirodnim resursima, izaziva strah i osjećaj nelagodnosti kod država širom svijeta, a naročito onih u njenom okruženju i bliskom susjedstvu. ${ }^{40}$ Dodatno, kinesko povezivanje sa evropskim kontinentom podrazumijeva pomorski i željeznički saobraćaj, koji će skratiti putovanje kineske robe, ali i uticati na značajno smanjenje cijene transporta. $\mathrm{Na}$ taj način, kineska roba postaće još konkurentnija na tržištu. ${ }^{41}$ Stoga, Inicijativu „Pojas i put" upoređuju sa Maršalovim planom, ${ }^{42}$ jer kineska ulaganja imaju

${ }^{36}$ Vanjskopolitička Inicijativa BH, ,Novi Put svile vodi preko Balkana: Kina i zemlje jugoistočne Evrope", Politička analiza 1/14, Sarajevo, jul 2014, str. 8.

${ }^{37}$ Ova inicijativa predstavlja ključni indikator kineske aspiracije za zauzimanje centralne uloge u regionu, djelujući uglavnom na ekonomskom nivou, ali ostvarujući političke i diplomatske benefite. (za više informacija pogledati: Chatham House, “The Critical Transition: China's Priorities for 2021", Research Paper, Edited by Kerry Brown, Asia Programme, The Royal Institute of International Affairs, London, February 2017, p. 8).

${ }^{38}$ Nova kineska strategija usmjerena na stvaranje mehanizama za saradnju Kine sa 16 država Centralne i Istočne Evrope. Ova strategija se posmatra kao nov regionalni pristup, baziran na jednakosti, uzajamnom poštovanju i koristi, ali i međusobnom razvoju, te zajedničkom težnjom za unaprijeđenje odnosa između Kine i Evrope.

${ }^{39}$ Tokom posjete Kazakstanu (2013. godine), kineski predsjednik Si Đinping (Xi Jinping) objavio je prilično nejasan plan za "Novi put svile“, kao dio velikog kineskog plana Inicijativa ",Pojas i put", u cilju izgradnje međunarodnog tržišta i infrastrukturnih puteva (za više informacija pogledati: Chantam House, op. cit., p. 37), odnosno Inicijativa predstavlja „,modernu inkarnaciju drevnog Puta svile“ (Slobodna Evropa, „Put svile ili put u dužništvo“, https:/ / www.slobodnaevropa.org/a/put-svile-italijakina-/29834859.html, pristup: 27.1.2021.).

${ }^{40}$ Borislav Marić, „,Novi 'Put svile ${ }^{\prime \prime}$, Anali poslovne ekonomije, br. 17, UDK 327:930.85(510); DOI 10.7251/APEI1717037M, 2017, str. 37-44.

${ }^{41}$ Vanjskopolitička Inicijativa BH, op. cit., str. 8.

${ }^{42}$ Postoji sličnost između Inicijative „Pojas i put" i Maršalovog plana. Dakle, Maršalov plan je za cilj imao upliv američke pomoći i kapitala u zapadnoj Evropi kako bi se zaustavilo širenje komunizma, dok kineska ulaganja u Inicijativu imaju za cilj uspostavljanje svjetske dominacije, kako bi dva glavna konkurenta, EU i Amerika, bili istisnuti iz ovih djelova svijeta. 
za cilj uspostavljanje svjetske dominacije, kako bi dva glavna konkurenta EU i Amerika bili istisnuti sa evroazijskog tržišta. S tim u vezi, oni podvlače da upravo Kina svojim privrednim i ekonomskim inicijativama nastoji da "oživi" trome ekonomije širom svijeta, zahvaljujućim novim putnim, željezničkim i pomorskim mrežama. Međutim, postoji i druga strana priče, gdje se ova vrsta inicijative posmatra kao potencijalna zamka za siromašnije partnere, odnosno kasnijeg preuzimanja značajnijih svjetskih ekonomija. Upravo zbog svega prethodno navedenog, dolazimo do teorije "opasne Kine", ${ }^{43}$ odnosno do uspona "uspavanog zmaja" ${ }^{44}$ koji namjerava da "zavlada" svijetom i nametne svoju politiku, kako predočava Farid Zakarija ${ }^{45}$ Ovakav stav ima prilično negativnu konotaciju, jer je „Novi put Kine" shvaćen kao latentna prijetnja za sve slabije evropske ekonomije, sa naznakom jačanja vojne i političke moći Kine, koja za cilj ima promjene unutar svjetskog poretka, koji se kreće u pravcu kineskog unipolarizma. Međutim, posmatrajući trenutnu situaciju u svijetu, nazire se isključivo jačanje multipolarizma globalnih regija. ${ }^{46}$

Podsjećanja radi, EU i Kina razgovaraju o politikama i pitanjima vezanim za trgovinu i investicije putem različitih sastanaka:

- Godišnji EU-Kina samit (na predsjedničkom nivou);

- Ekonomski i trgovinski dijalog na visokom nivou između EU i Kine (potpredsjednik EU i potpredsjednik kineske vlade);

- Zajednička komisija za trgovinu (godišnji sastanak na ministarskom nivou);

- Dijalog o trgovinskoj i investicionoj politici (sastanak na nivou generalnih direktora);

- Radna grupa za ekonomiju i trgovinu (rasprave između stručnjaka). ${ }^{47}$

Majkl Smit (Michael Smith) prepoznaje tri oblika policy making-a Evropske unije na međunarodnom nivou. Prvi je stvaranje politika na nivou Zajednice (najbolji primjer za to je trgovinska politika), drugi je stvaranje politika na nivou Unije (u tom kontekstu nastaje Zajednička vanjska i sigurnosna

${ }^{43}$ Lazar Radisavljević, „Da li je Inicijativa pojas i put kineska verzija Maršalovog plana?", CMJP, 2020, http://cmjp.rs/da-li-je-inicijativa-pojas-i-put-kineska-verzija-marsalovogplana/, pristup. 27.1.2021

${ }^{44}$ Ibidem

${ }^{45}$ Fareed Zakaria, "The Self-Destruction of American Power: Washington Squandered the Unipolar Moment", Foreign Affairs, 2019, https://www.foreignaffairs.com/articles /2019-06-11/self-destruction-american-power, pristup: 27.1.2021.

${ }^{46}$ Radovan Vukadinović, „,Međunarodni odnosi od Hladnog rata do globalnog poretka”, CID, Podgorica, 2009, str. 318-319 i 338.

${ }^{47}$ European Commission, URL: https://ec.europa.eu/trade/policy/countries-and80 regions/countries/china/, pristup: 12.5.2020. 
politika, no razlika između toga i običnog međuvladinog pristupa je izražena uloga Evropske komisije u prvom pristupu), a treći je stvaranje politika kroz proces pregovora na više nivoa (na primjer, unutar Svjetske trgovinske organizacije, WTO-a). ${ }^{48}$ Dodatno, prema istraživanju Trgovinske komore Evropske unije u Kini, 71\% kineskih učesnika ankete je kao glavni razlog investiranja u zemlje EU navelo pristup zajedničkom tržištu Unije. ${ }^{49}$ Analogijom, ovo bi mogao biti razlog investiranja i u zemlje van $\mathrm{EU}(\mathrm{BiH}$, Srbija i dr.) s obzirom na to da one imaju potpisane sporazume o slobodnoj trgovini s EU, ali i s Turskom i Rusijom. Ipak, pristup tržištu nije bez prepreka, tako da je skoro polovina učesnika ankete navela da se pri investiranju u EU susretala s raznim poteškoćama. Isto istraživanje mnjenja kineskih investitora, međutim, ukazuje na poboljšanje uslova investiranja, nakon što se finansijska i dužnička kriza ${ }^{50}$ proširila starim kontinentom.

\section{Virus COVID-19. Put naprijed.}

Krajem 2019. godine, svijetom se proširila vijest o novom koronavirusu, za koji su se pojavile sumnje da je nastao i razvio se na pijaci u Vuhanu. Vremenom, virus se proširio širom svijeta, zavladala je svjetska pandemija, a milioni ljudi su izgubili svoje živote. Među ljudima se pojavila averzija kako prema Kini tako i prema kineskom narodu, jer se u početku sticao utisak da je baš narod „žute rase” glavni prenosilac opasnog virusa. „Prije nešto više od jednog vijeka, tačnije 1900. godine, u San Francisku je izbila epidemija bubonske kuge. Na sličan način je reagovao čuveni američki ljekar Volter Vitman (Walter Wytman), koji je bubonsku kugu definisao kao "orjentalnu bolest, karakterističnu za rižojedce". ${ }^{51}$

Međutim, neophodno je istaći da bez obzira na brojne pretpostavke (gdje i na koji način se ovaj virus pojavio: pijaca mješovite robe u Vuhanu), zatim brojnih teorija zavjere i negativnih propagandnih kampanja usmjerenih protiv Kine i kineskog naroda, može se reći da je tokom pandemije koronavirusa u 2020. godini Kina postigla mnogo bolje rezultate nego ostali, te na taj način ostvarila značajne benefite, tj. prevenstveno je ekonomski profitirala, "potisnuvši na taj način Ameriku sa svjetskog

${ }^{48}$ Michael Smith, 2006: "The EU as an international actor" u: Richardson, Jeremy (ur.) 2006:

"European Union: Power and policy-making", New York: Routledge, pp. 289-309.

${ }^{49}$ European Union Chamber of Commerce in China, 2013, p. 17.

${ }^{50}$ Nakon finansijske krize koja je obilježila 2008. godinu, mnogobrojne države su zapale $\mathrm{u}$ finansijske probleme, što je uzrokovalo promjene na međunarodnoj sceni. Na taj način, odnos prema Kini se drastično mijenja, te se značajan dio međunarodne zajednice okreće ka njoj, odnosno novom izvoru ekonomske moći.

${ }^{51}$ Nikola Zečević, ,„Koronacionalizam“ , Peščanik, 2020, dostupno na: https:/ / pescanik.net/ koronacionalizam/, pristup: 12.7.2020. 
trona" ${ }^{52}$ Bitno je pomenuti da je samo tokom prvog talasa ove krize, Kina ${ }^{53}$ bila najveći svjetski proizvođač maski za lice, ali i zaštitne odjeće i sredstava za dezinfekciju ruku, te cjelokupnog materijala za borbu protiv koronavirusa, ali ipak nije uspijevala u potpunosti ispratiti potrebe svjetskog tržišta. ${ }^{54}$ Pored toga, Kina je bila proaktivna država koja je pružala značajnu pomoć, slala svoje ljekare i medicinski materijal u mnoge zemlje svijeta, šireći na taj način poruke prijateljstva, indirektno namećući svoj uticaj i značaj u svijetu (koristeći soft power).

Za razliku od Kine, Evropska unija je ostala nemoćna i paralisana pred nastalim problemom. Nije uspijevala da pronađe adekvatan odgovor $\mathrm{i}$ efikasno djeluje. Članice Unije su brzinski počele sa zatvaranjem nacionalnih granica, zaboravljajući na solidarnost, okrećući se sebi samima, te zanemarujući osnivačke principe Unije, ali i ključni slogan - „ujedinjeni u raznovrsnosti". Krajnje egoističan stav je vremenom počeo da blijedi i nestaje, ustupajući mjesto zajedničkoj spremnosti za rješavanje pandemije, ali i ublažavanje društveno-ekonomskih posljedica. Pa je tako, Evropska komisija preduzela inicijativu kako bi izašla na kraj sa ovom globalnom prijetnjom, raspolažući paketom u vrijednosti od 15,6 milijardi evra pomoći, uz adekvatno pružanje pomoći i aktivno djelovanje partenera EU. Naravno, kao dio globanog odgovora na ovu pandemiju, nešto više od 3,8 milijardi evra izdvojeno je za Zapadni Balkan i njene neposredne susjede na sjeveru i jugu, gdje je postojala stvarna potreba za novčanim i medicinskim sredstvima. Takođe, EU kao globalni akter, kako vrijeme odmiče, nastavlja da se prilagođava situaciji unutar međunarodne zajednice, te će u budućem periodu svoju pažnju posebno usmjeriti na ugrožena i siromašna područja, poput Afrike, ali i Bliskog istoka, Zapadnog Balkana, u pojedinim djelovima Azije, Latinske Amerike itd. Dakle, formiranjem Tima Evrope, stavljen je akcenat na pružanje brze i ciljane pomoći i podrške partnerima EU koji se aktivno bore sa ovom pandemijom. Stoga je važno naglasiti da se prvi paket ovog Tima, aktivno primjenjuje na područje Zapadnog Balkana. ${ }^{55}$

${ }^{52}$ Economist, "Is China winning?", 2020, https://www.economist.com/leaders/2020/ 04/16/is-china-winning, pristup: 12.7.2020.

${ }^{53}$ BYD Co poznat kao najveći kineski proizvođač električnih automobila, tokom vanrednog stanja rekonfigurisala je svoje proizvodne kapacitete, tako da je proizvodila maske za lice i sredstva za dezinfekciju (Prema podacima iz marta 2020. godine, BYD kompanija je proizvodila 5 miliona maski za lice i 300.000 boca dezinfekcionih sredstava za ruke dnevno).

${ }^{54}$ Adnan Huseinagić, "BYD je najveći proizvođač zaštitinih maski na svijetu”, https:/ / proauto.ba/byd-je-najveci-proizvodac-zastitnih-maski-na-svijetu/, pristup: 12.7.2020.

${ }^{55}$ Delegacija Evropske unije u Republici Srbiji, http://europa.rs/globalni-odgovor-euu-borbi-protiv-pandemije-covid-19-preko-15-milijardi-evra-za-partnere-i-susedsne-

82 zemlje/, pristup: 1.10.2020. 


\section{Zaključak}

Kina je zakoračila u XXI vijek sa jasnom težnjom da povrati svoju staru slavu, nakon takozvanog „,stoljeća narodnog poniženja” ${ }^{56}$ Međutim, ona je svoju ogromnu ambiciju i samopouzdanje potvrdila epitetom ekonomske supersile, na što upućuje njen ekonomski rast u posljednje četiri decenije, koji u prosjeku na godišnjem nivou iznosi $10 \%$, ali i njenog uspješnog balansiranja na međunarodnoj političkoj sceni, što je uticalo da Kina započne sa potražnjom novih tržišta, ali i izvora energije. ${ }^{57}$

Kina je danas zemlja koja izaziva ogromnu pažnju svjetskih analitičara i ekonomista, upravo zbog ogromnog rasta BDP-a, ali i zbog svoje jasne dominantnosti u svijetu na nekoliko različitih polja. Dodatno, Kina je svojom jasnom ekonomskom založenošću za napretkom, za saradnjom sa velikim međunarodnim akterima stavila do znanja svima da joj je cilj kooperacija i na taj način učvrstila svoje odnose sa EU, ali i sa velikim brojem azijskih zemalja.

Uzimajući u obzir istoriju međunarodnih odnosa, možemo se usuditi da zaključimo da je XIX vijek bio vijek Evrope, XX vijek Amerike, a sve se više čini da će vijek u kome živimo - biti vijek velike azijske sile Kine. Ukoliko se osvrnemo na trenutnu situaciju sa pandemijom korona virusa na globalnom nivou, neophodno je naglasiti da je Kina istakla dominantne crte svoje snage i sposobnosti naprednijeg, što nije bio slučaj sa Evropskom unijom.

Evropska unija je, kao što smo i predočili u radu, projekat koji je formalno nastao sredinom XX vijeka na temeljima porušene Evrope. Danas, ona funkcioniše na talasima velikog broja evropskih zemalja, uključujući i saradnju sa vanevropskim faktorima, kao što su Kina i SAD. U igri velikih, Evropska unija zauzima ozbiljno mjesto. Ako se osvrnemo na istoriju, Kina je ponekad bila na poziciji posmatrača poredaka koji su se dešavali u svijetu. Danas, Kina je jedan od ključnih aktera u međunarodnim odnosima, sa jasnom ideologijom i jasnim ciljem. Upravo iz tog razloga, sve se više čini da će oni koji su bili ključni akteri na svjetskoj političkoj sceni preći na mjesta posmatrača, a da će bivši posmatrači postavljati pravila i temelje modernog svjetskog poretka.

\section{Bibliografija}

Baković, Ozren, „MMiroljubivi uspon - nova kineska vanjskopolitička teorija”, Politicka misao, Vol. XLI, (2004.), br. 1, str. 126-137.

Baylis, John, Smith, Steve and Owens, Patricia, "The Globalization of World Politics", Oxford University Press, Oxford, 2014.

\footnotetext{
${ }^{56}$ Vanjskopolitička Inicijativa BH, op. cit., str. 3.

${ }^{57}$ Ibidem
} 
Beyer, Sylvia, "Environmental Law and Policy in the People's Republic of China", Chinese Journal of International Law, 1/2006, p. 187.

Chatham House, "The Critical Transition: China's Priorities for 2021", Research Paper, Edited by Kerry Brown, Asia Programme, The Royal Institute of International Affairs, London, February 2017.

Van Langenhove, Luk, "The EU as a Global Actor in a Multipolar World and Multilateral 2.0 Environment", Egmond Paper 36, Egmond - The Royal Institute for International Relations, Brussels, Belgium, 2010, p. 5. http://www.cris.unu.edu/fileadmin/user_upload/Egmont_paper_36_ by_Luk_Van_Langenhove.pdf.

Van Schaik, Louise and Schunz, Simon, "Explaining EU Activism and Impact in Global Climate Politics: Is the Union a Norm- or Interest-Driven Actor?", JCMS: Journal of Common Market Studies, 1/2012, pp. 169-186.

Vanjskopolitička Inicijativa BH, ,Novi Put svile vodi preko Balkana: Kina i zemlje jugoistočne Evrope", Politička analiza 1/14, Sarajevo, jul 2014.

Vukadinović, Radovan, „Međunarodni odnosi od Hladnog rata do globalnog poretka", CID, Podgorica, 2009.

Dabetić, Zoran, „Uporedna analiza iskustava Crne Gore i Slovenije u procesu pristupanja Evropskoj uniji: analiza spoljne politike“, Magistarski rad, Univerzitet Donja Gorica, Podgorica, 2019.

Đurović, Gordana, „Evropska unija i Crna Gora: proces pristupanja”, Nacionalna biblioteka Crne Gore, Podgorica, 2017.

Zongze, Ruan, predavanje na temu: "China's Peaceful Rise And Chinese Foreign Policy", 3. travnja 2004.

Zhaorong, Mei, "New Phase In China-EU Relations", Foreign Affairs Journal, 2004.

Zhongping, Feng, "A Chinese perspective on China-European relations", European Union Institute for Security Studies (EUISS), 2008.

Jordan, Andrew, "An ever more environmental union amongst the peoples of Europe?", Taylor \& Francis Online, Environmental Politics, 3/2008, Vol. 17, pp. 485-491.

Kisindžer, Henri, „,Svetski poredak“, CID, Podgorica, 2015.

Marić, Borislav, „Novi 'Put svile'“, Anali poslovne ekonomije, br. 17, UDK 327:930.85(510); DOI 10.7251/APEI1717037M, 2017, str. 37-44.

Maršal, Tim, ,"Zatočenici geografije" , Laguna, Beograd, 2019.

Medeiros, Evan S. and Fravel, Taylor, "China's New Diplomacy", Foreign Affairs, 2003, p. 22.

Plevnik, Jasna, Mesić, Stjepan i Jurčić, Ljubo „Kina na Balkanu”, Plejada, 84 Zagreb, 2012. 
Smith, Michael, 2006: "The EU as an international actor" u: Richardson, Jeremy (ur.) 2006: "European Union: Power and policy-making", New York: Routledge, pp. 289-309.

Muldavin, Joshua, "The Paradoxes of Environmental Policy and Resource Management in Reform-Era China", Economic Geography, 3/2000, p. 255.

Schlosberg, David and Rinfret, Sara, "Ecological modernisation, American style", Routledge, Taylor \& Francis Group, Environmental Politics, 2/2008, Vol. 2, pp. 254-275.

Džombić, Ilija J., „Evropske inicijative i institucije” - II izdanje, Friedrich-EbertStiftung, Sarajevo, 2012.

Xin, Chen, "Policy Evolution of the China-EU Trade and Economic Relantionship" Working Paper Series on European Studies, Institute of European Studies, Chinese Academy of Social Sciences, Beijing 100732, Vol. 3, No. 4, 2009.

\section{Linkovi}

Delegacija Evropske unije u Republici Srbiji, dostupno na: http:/ / europa.rs / globalni-odgovor-eu-u-borbi-protiv-pandemije-covid-19-preko-15milijardi-evra-za-partnere-i-susedsne-zemlje/

Economist, "Is China winning?", 2020. https://www.economist.com/ leaders/2020/04/16/is-china-winning

European Commission, URL: https:/ /ec.europa.eu/trade/policy/countriesand-regions/countries/china

Huseinagić, Adnan, „BYD je najveći proizvođač zaštitinih maski na svijetu”, Proauto, 2020, dostupno na: https://proauto.ba/byd-je-najveciproizvodac-zastitnih-maski-na-svijetu/

Radisavljević, Lazar, „Da li je Inicijativa pojas i put kineska verzija Maršalovog plana?", CMJP, 2020. Dostupno na: http://cmjp.rs/da-li-je-inicijativapojas-i-put-kineska-verzija-marsalovog-plana/

Slobodna Evropa, „Put svile ili put u dužništvo“, 2019, dostupno na: https:// www.slobodnaevropa.org/a/put-svile-italija-kina-/29834859. htmlhttps://www.slobodnaevropa.org/a/put-svile-italija-kina-/298348 59.html

Zakaria, Fareed, "The Self-Destruction of American Power: Washington Squandered the Unipolar Moment", Foreign Affairs, 2019, https:// www.foreignaffairs.com/articles/2019-06-11/self-destruction-americanpower

Zečević, Nikola, „,Koronacionalizam“, Peščanik, 2020, https:// pescanik.net/ koronacionalizam/ 
Zvanični Sajt EUR-LEX-a, dostupno na: https://eur-lex.europa.eu/ content/news/Brexit-UK-withdrawal-from-the-eu.html

Zvanični sajt Evropske komisije, dostupno na: https://ec.europa.eu/ commission/priorities/state-union-speeches_hr

Zvanični sajt Parlamenta Ujedinjenog Kraljevstva, dostupno na: https:// www.parliament.uk/business/publications/research/eureferendum/leaving-the-european-union/ .

\title{
EU AND CHINA- POLITICAL AND ECONOMIC ASPECT OF COOPERATION
}

\begin{abstract}
This paper aims to analyse the political, economic and legal aspects of cooperation between the European Union and China through the prism of common economic interests and economic complementarity. In the introductory part, the authors talk about the historical development of China as a state and its transformation in both political and economic terms. Special attention is paid to the historical development of relations between China and the European Union, with an emphasis on the development of economic, political and trade cooperation. These relations, among others, stand out as key in China's foreign policy priorities. In addition, the Belt and Road Initiative will be briefly explained, but the COVID-19 pandemic will also be discussed, as well as China's crucial role in this pandemic that has struck and changed the world.

Keywords: EU, China, politics, history, geo-economics, world order, Belt and Road Initiative, COVID-19.
\end{abstract}

